\title{
Bacterial laccase of Anoxybacillus ayderensis SK3-4 from hot springs showing potential for industrial dye decolorization
}

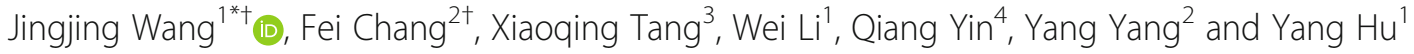

\begin{abstract}
Introduction: Laccases are green biocatalysts that possess attractive for the treatment of resistant environmental pollutants and dye effluents.

Purpose: To exploit the laccase of Anoxybacillus ayderensis SK3-4 that possesses dye decolorization ability at room and higher temperature, we characterized the enzyme in considerable detail and investigated its ability to decolorize different dyes.

Results: A bacterial laccase gene designed as LacAn from Anoxybacillus ayderensis SK3-4 of hot springs was cloned and expressed in Escherichia coli. LacAn is a monomeric protein with a molecular weight of $29.8 \mathrm{kDa}$. The optimum $\mathrm{pH}$ and temperature for syringaldazine oxidation were 7.0 and $75^{\circ} \mathrm{C}$, respectively. LacAn was stable at pH values ranging from 6.5 to 8.5 above $65^{\circ} \mathrm{C}$. The enzyme activity was significantly enhanced by $\mathrm{Cu}^{2+}$ and $\mathrm{Mg}^{2+}$ but inhibited by $\mathrm{Zn}^{2+}$ and $\mathrm{Fe}^{2+}$. Furthermore, LacAn showed high decolorization capability toward five dyes (direct blue 6 , acid black 1, direct green 6 , direct black 19, and acid blue 93) in the absence of redox mediators. It also demonstrated a wide temperature range, and it can retain its high decolorization ability even at high temperatures. Conclusions: These properties including better enzymatic properties and efficiency to decolorize dyes demonstrate that the bacterial laccase LacAn has potentials for further industrial applications.
\end{abstract}

Keywords: Anoxybacillus ayderensis SK3-4, Laccase, Purification, Characterization, Decolorization

\section{Introduction}

Laccases (benzenediol: oxygen oxidoreductases, EC 1.10.3.2) are a family of multicopper oxidases widely distributed in the bacteria, fungal, insect, plant kingdoms, and particularly in basidiomycetes polyphenols. They catalyze the one-electron oxidation of a wide range of aromatic compounds including phenols and amines by coupling to the reduction of oxygen to water (Hoegger et al., 2006; Baldrian, 2006). Laccases have been considered as green and environmentalfriendly biological catalysts and have been the focus of an increasing contemporary investigation due to their

\footnotetext{
*Correspondence: wjj_0203@126.com

†jingjing Wang and Fei Chang contributed equally to this work.

${ }^{1}$ School of Life Science, Hefei Normal University, Hefei 230601, Anhui, China

Full list of author information is available at the end of the article
}

diverse potential biotechnological applications, such as dye decolorization, biopulping, biobleaching, xenobiotic degradation, food processing, biopolymer modification, ethanol production, biosensor development, drug synthesis, and organic synthesis (Telke et al., 2011; Kudanga and Le Rose-Hill, 2014; Mate and Alcalde, 2016).

In the early stage of laccase application, the biological roles of fungal and plant laccases have been thoroughly studied and shown to be related to the degradation and synthesis of lignin (Leonowicz et al., 2001). However, recent studies have discovered that laccases are widespread in bacteria, such as Bacillus tequilensis (Sonica et al., 2014), Caldalkalibacillus thermarum (Sunil et al., 2018), Streptomyces griseorubens (Feng et al., 2015), and Agaricus bisporus (Othman et al., 2018), and their application is common in the industrial field. Industrial processes

(c) The Author(s). 2020 Open Access This article is licensed under a Creative Commons Attribution 4.0 International License, which permits use, sharing, adaptation, distribution and reproduction in any medium or format, as long as you give appropriate credit to the original author(s) and the source, provide a link to the Creative Commons licence, and indicate if changes were made. The images or other third party material in this article are included in the article's Creative Commons licence, unless indicated otherwise in a credit line to the material. If material is not included in the article's Creative Commons licence and your intended use is not permitted by statutory regulation or exceeds the permitted use, you will need to obtain permission directly from the copyright holder. To view a copy of this licence, visit http://creativecommons.org/licenses/by/4.0/. 
usually include harsh conditions, such as high temperature, acidic or alkaline $\mathrm{pH}$, and high salt and detergents; thus, some laccases that are resistant to these harsh conditions are preferable (Hilden et al., 2009; Gunne and Urlacher, 2012). Of the reported bacterial laccases, several possess distinctive properties, including excellent activity and stability under alkaline conditions. For example, the Tth laccase from Thermus thermophilus exhibits extreme stability against heat with a half-life of more than $14 \mathrm{~h}$ at $80{ }^{\circ} \mathrm{C}$ (Miyazaki, 2005). The Ssl1 laccase from Streptomyces sviceus is highly alkali stable and resistant to detergents and organic solvents (Gunne and Urlacher, 2012). In addition, the SN4 laccase from Bacillus tequilensis is thermo-alkali stable and metal tolerant (Sonica et al., 2014). Bioinformatics analysis has demonstrated the high diversity of laccase or laccase-like enzymes in bacteria (Ausec et al., 2011), but bacterial laccase-like enzymes have yet to be exploited as promising laccase resources.

In this study, a putative laccase-like gene (designated lacAn) from Anoxybacillus ayderensis SK3-4 was cloned and heterologously expressed in Escherichia coli BL21 (DE 3). Anoxybacillus ayderensis SK3-4 was isolated from the Sungai Klah (SK) and Dusun Tua (DT) hot springs in Malaysia (Kahar et al., 2013). To exploit the laccase of Anoxybacillus ayderensis SK3-4 that possesses dye decolorization ability at room and higher temperature, we characterized the enzyme in considerable detail and investigated its ability to decolorize different dyes. LacAn possessed great enzymatic properties in terms of biochemical characteristics. The potential of the enzyme in the decolorization of industrial dyes in the absence of mediators was also evaluated.

\section{Materials and methods Chemicals}

2,6-Dimethoxyphenol and 2,2'-azinobis (3-ethylbenzthiazoline-6-sulfonate) (ABTS), syringaldazine (SGZ), and 4-fluoro-2-methylphenol were from Sigma. Restriction enzymes and DNA ligase were from New England Biolabs (MA, USA). Agarose gel DNA extraction kit was from Qiagen, Hilden, Germany. Taq DNA polymerase and isopropyl- $\beta$-D-thiogalactoside (IPTG) were purchased from TaKaRa (Dalian, China). Direct blue 6 (DB6), acid black 1 (AB1), direct green 6 (DG6), direct black 19 (DB19), and acid blue 93 (AB93) were from SigmaAldrich (St. Louis, MO, USA). All other chemicals and reagents were of analytical grade.

\section{Microorganisms and maintenance}

E. coli BL21(DE3) was purchased from TransGen (Beijing, China) and was used as the host strain for plasmid propagation and protein expression. The E. coli strain was routinely grown in Luria-Bertani medium.
Cloning, expression, purification, and verification of identity

A series of potential laccase sequences were obtained on NCBI through bioinformatics technology (the access no. EPZ38526.1 from GeneBank). The target laccase-like gene (designated lacAn) was selected from Anoxybacillus sp. and optimized according to $E$. coli preference. Then the sequence was sent to General Biosystems (Anhui, China) for synthesis (Fig. S1). Finally, the synthesized sequence is inserted into the vector pUC18.

The open reading frame (a 804-bp fragment) of LacAn was amplified using the primer pair of GATA TACATATGAACGATATATTTCGCCAAG (Nde I site italicized) and GTGGTGCTCGAGCCTCCAGC CAATAAGCGC (Xho I site italicized) based on the optimized gene sequence (pUC18-LacAn). Construction of plasmid pET22b-LacAn was performed according to the methods of Fang et al. (Fang et al., 2011). E. coli BL21(DE3) cells carrying pET22b-LacAn were grown at $37{ }^{\circ} \mathrm{C}$ in $200 \mathrm{~mL}$ of LB medium containing $100 \mu \mathrm{g} / \mathrm{mL}$ ampicillin. The cultivation temperature was reduced to 16 ${ }^{\circ} \mathrm{C}$, and IPTG at a final concentration of $0.2 \mathrm{mM}$ was added into the culture to induce enzyme expression when the $\mathrm{OD}_{600}$ of culture medium reached 0.6. After an additional incubation for $16 \mathrm{~h}$, the cells were collected by centrifugation. The pellets were resuspended in cold 20 $\mathrm{mM}$ Tris- $\mathrm{HCl}$ buffer (pH 7.9) containing $500 \mathrm{mM} \mathrm{NaCl}$ and $5 \mathrm{mM}$ imidazole, disrupted by sonication, and then centrifuged at $30,000 \times g$ for $30 \mathrm{~min}$. The supernatant was applied to Ni-NTA (Novagen, Darmstadt, Germany) affinity chromatography to purify the recombinant LacAn. The purified protein was stored at $4{ }^{\circ} \mathrm{C}$.

The molecular mass of the denatured protein was estimated by sodium dodecyl sulfate (SDS) polyacrylamide gel electrophoresis (PAGE). Proteins were stained with Coomassie brilliant blue R-250. Activity staining of LacAn was performed in $50 \mathrm{mM} \mathrm{Na} \mathrm{NPO}_{4}-\mathrm{KH}_{2} \mathrm{PO}_{4}$ buffer (pH 7.0) containing different substrates and $10 \mu \mathrm{M} \mathrm{CuSO}$. Protein concentration was determined using the BAC method (Bio-Rad, USA).

\section{Sequence analysis of IacAn}

The ORF of lacAn was determined using the ORF Finder provided by the National Center for Biotechnology Information (http://www.ncbi.nlm.nih.gov/gorf/gorf. html). Similar sequence searching was performed using BlastP at NCBI. The module structure of the enzyme was analyzed with simple modular architecture research tool SMART (http://smart.embl-heidelberg.de/). Multiple sequence alignment of lacAn with other related laccase sequences was performed using Clustal X 2.0.

\section{Enzyme assay}

The assay mixture consisted of $10 \mu \mathrm{L}$ of appropriately diluted LacAn stock and $990 \mu \mathrm{L}$ of $50 \mathrm{mM} \mathrm{Na} \mathrm{NPO}_{4}$ - 
$\mathrm{KH}_{2} \mathrm{PO}_{4}$ buffer (pH 7.0) containing $100 \mu \mathrm{M}$ SGZ (65, $000 \mathrm{M}^{-1} \mathrm{~cm}^{-1}$ ) and $10 \mu \mathrm{M} \mathrm{CuSO} \mathrm{M}_{4}$. The reaction was initiated by adding SGZ and enzyme into the solution. After incubation at $45{ }^{\circ} \mathrm{C}$ for $5 \mathrm{~min}$, the mixture was transferred into ice-water bath for $30 \mathrm{~s}$ to stop the reaction and the absorbance was measured at $525 \mathrm{~nm}$ using a UV-visible spectrophotometer (Shimadzu uv-vis 1700, Japan). Alternative substrates for the measurement of laccase activity were $2 \mathrm{mM}$ 2,6-DMP. Reactions with heat-treated LacAn were used as control. One activity unit $(\mathrm{U})$ was defined as the amount of LacAn for oxidizing $1 \mu \mathrm{mol}$ of substrate per minute. Protein concentration of LacAn was determined at $595 \mathrm{~nm}$ using the Modified Bradford Protein Assay Kit (Sangon, China) as bovine serum albumin as the standard.

\section{Characterization of LacAn}

The effect of $\mathrm{pH}$ on laccase activity was examined in the $\mathrm{pH}$ range of 4.5-9.0. Sodium citrate buffer ( $\mathrm{pH} 4.5-5.5)$, $\mathrm{Na}_{2} \mathrm{HPO}_{4}-\mathrm{KH}_{2} \mathrm{PO}_{4}$ buffer (pH 5.5 to 8.0), and Tris- $\mathrm{HCl}$ buffer ( $\mathrm{pH}$ 8.0-9.0) were used at a final concentration of $50 \mathrm{mM}$. The enzyme stability against $\mathrm{pH}$ was determined by measuring the residual activities of LacAn after incubation at $4{ }^{\circ} \mathrm{C}$ for $1 \mathrm{~h}$ in the aforementioned buffers. The effect of temperature on the activity was measured by incubating LacAn at $\mathrm{pH} 7.5$ and a temperature range of $40-80{ }^{\circ} \mathrm{C}$. Thermostability was determined by incubating LacAn at various temperatures $\left(15-55^{\circ} \mathrm{C}\right)$ at $\mathrm{pH} 7.5$ for $15 \mathrm{~min}$. The values and standard deviations are calculated based on three independent experiments.

The effects of $0.1 \mathrm{mM} \mathrm{Mg}^{2+}, \mathrm{Co}^{2+}, \mathrm{Zn}^{2+}, \mathrm{Ca}^{2+}, \mathrm{Fe}^{2+}$, EDTA 5\% dimethyl sulfoxide (DMSO), $0.5 \mathrm{mM}$ SDS, and $5 \%$ ethanol on LacAn activity were investigated by incubating LacAn with each effector for $15 \mathrm{~min}$ at $4{ }^{\circ} \mathrm{C}$ prior to substrate SGZ addition. The laccase assays were carried out under the aforementioned conditions. Control was carried out under the conditions with $\mathrm{Na}_{2} \mathrm{SO}_{4}$, $\mathrm{KCl}$, or without $\mathrm{NaCl}$ in the normal manner.

\section{Decolorization of textile azo dyes}

The LacAn was used to oxidize 5 synthetic dyes of different classes which were shown in Table 1 . The chemical structures of these dyes were shown in an additional figure (Fig. S2). Initial solutions $(10 \mathrm{mM})$ of these dyes were prepared in DMSO and diluted to the required concentration and then used for the reaction. Initially, the reaction was mixture $1 \mathrm{~mL}$ contained 50 $\mathrm{mM}$ citrate-phosphate buffer ( $\mathrm{pH} 7.5$ ), crude enzyme $(200 \mathrm{U} / \mathrm{L})$, and dye solution $(100 \mu \mathrm{M})$.

To evaluate the effect of the conditions on dye decolorization, the $\mathrm{pH}$ (5.5-8.5), temperature (55-80 $\left.{ }^{\circ} \mathrm{C}\right)$, enzyme amount (50-250 U/L), and time (20-140 min) were optimized in turn. The reactions were incubated for $2 \mathrm{~h}$, and the boiled LacAn as the control. The decolorization of these dyes by LacAn was monitored by the decrease in absorbance at the wavelength of each dye. The decolorization ratio was calculated according to the following equation:

Decolorization ratio $(\%)=(A-\mathrm{A} 0) / \mathrm{A} 0 \times 100 \%$

$\mathrm{A} 0$ and $A$ represented the initial and final absorbance of the dye, respectively.

\section{Results and discussion}

\section{Analysis of the LacAn sequence}

The putative ORF of lacAn consists of 804 nucleotides that encode a protein containing 267 amino acid residues. Putative conserved domains were detected according to the Pfam database (Pfam PF02578), demonstrating that LacAn belongs to the $\mathrm{Cu}$-oxidase_4 superfamily (Beloqui et al., 2006). The relationship between lacAn and multiple selected laccase genes is shown in Fig. 1. Among the 12 identified copper sites in RL5, all sites were conserved in $l a c A n$, which proved that LacAn is a bacterial laccase (Beloqui et al., 2006).

\section{Purification of LacAn}

After preliminary optimization of expression and purification, a protein with laccase activity and molecular mass of about $29.8 \mathrm{kDa}$ (Fig. 2), named LacAn, was obtained. Under the corresponding optimum condition, the specificity of LacAn was $3.2 \mathrm{U} \mathrm{mg}^{-1}$ with substrate SGZ. At present, the molecular mass of most fungi and bacterial laccases range from 50 to $100 \mathrm{kDa}$ (Brijwani et al., 2010; Sharma et al., 2007). However, the molecular mass of LacAn is only $29.8 \mathrm{kDa}$. Similar conditions were also found in the laccase protein SN4LAC of B. tequilensis (Sonica et al., 2014). Sondhi et al. suggested that this difference in molecular mass makes SN4LAC an interesting protein for studying the structure-function relationship of laccases (Sonica et al., 2014).

Table 1 Characteristics of dyes used in this study

\begin{tabular}{lllll}
\hline Dye & Abbreviation & Classification & Wave length (nm) & Molecular weight \\
\hline Direct green 6 & DG6 & Azo & 514 & 812.70 \\
Direct black 19 & DB19 & Azo & 514 & 839.77 \\
Direct blue 6 & DB6 & Azo & 520 & 932.76 \\
Acid black 1 & AB1 & Azo & 520 & 616.49 \\
Acid blue 93 & AB93 & Anthraquinone & 600 & 799.79 \\
\hline
\end{tabular}



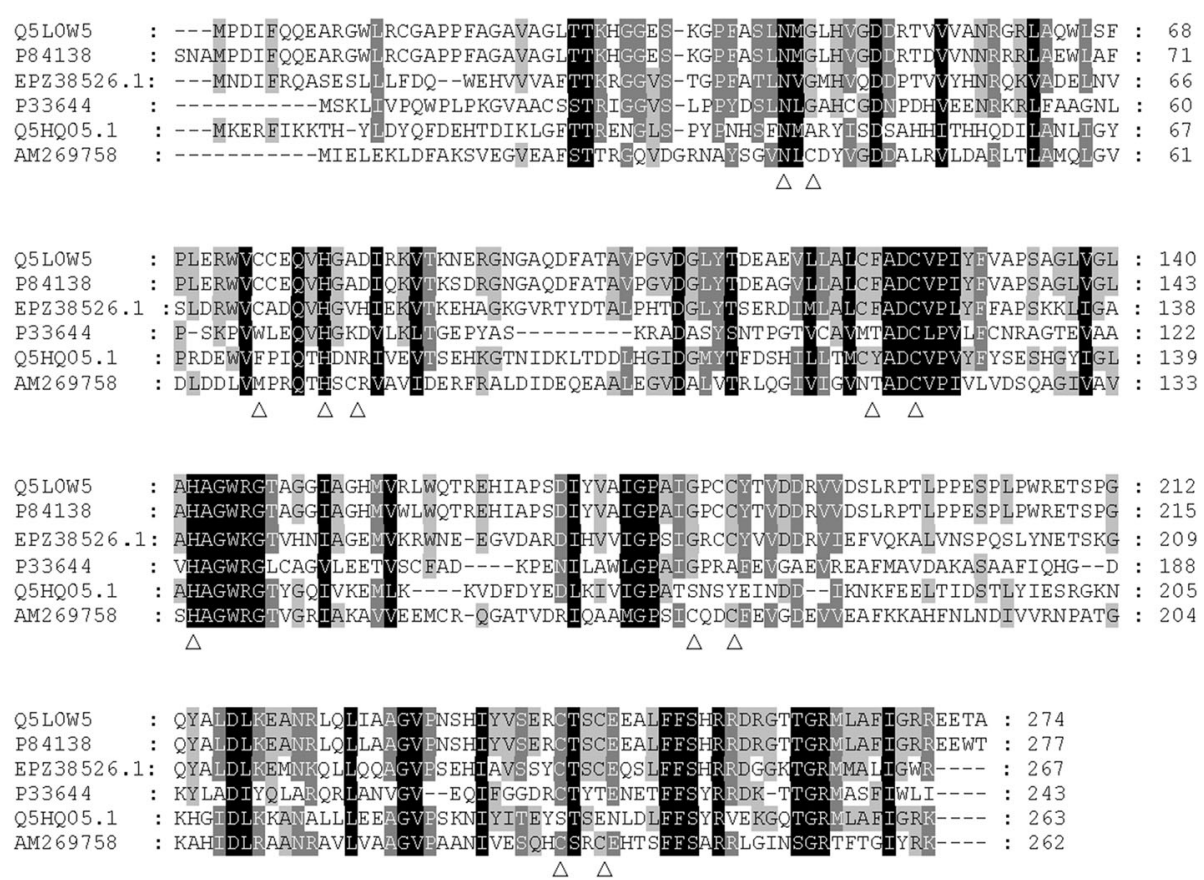

Fig. 1 Multiple sequence alignment of LacAn with selected LacAn-related proteins. Amino acid sequences were retrieved from NCBI or the UniProt database. LacAn, a copper oxidase in this study (GeneBank accession no. EPZ38526.1); yfiH, a laccase from E. coli (UniProt accession no. P33644); 1t8h (UniProt accession no. P84138), Q5HQ05.1, Q5LOW5 were uncharacterized proteins from Bacillus stearothermophilus, Staphylococcus epidermidis RP62A, and Geobacillus kaustophilus; RL5, a laccase from the bovine rumen metagenome (NCBI accession no. AM269758). The amino acid residues binding to the three copper sites in RL5 are indicated with $\Delta$

\section{Characterization of LacAn}

The optimum temperature of the purified LacAn was 75 ${ }^{\circ} \mathrm{C}$ (Fig. 3a). LacAn displayed more than $60 \%$ of the maximal activity with $180 \mathrm{~min}$ from 25 to $45^{\circ} \mathrm{C}$. In addition, the enzyme was stable at relatively high temperatures, with a half-life of $155 \mathrm{~min}$ at $65{ }^{\circ} \mathrm{C}$ when syringaldazine was used as a substrate (Fig. 3b). Obviously, LacAn, similar to many discovered bacterial laccases, showed great thermostability even at temperatures above $60{ }^{\circ} \mathrm{C}$ (Table S1). In addition, environmental factors also affected its thermostability. Anoxybacillus ayderensis SK3-4 originated from hot springs, which have a high temperature environment, explaining the stable thermostability of LacAn.

Conversely, LacAn displayed the maximum activity at $\mathrm{pH} 7.0$ (Fig. 3c). It was stable at $\mathrm{pH}$ values ranging from 6.5 to 8.5 at $75{ }^{\circ} \mathrm{C}$ and was the most stable at $\mathrm{pH} 7.5$, retaining more than $80 \%$ of the original activity after incubation at $75{ }^{\circ} \mathrm{C}$ for $180 \mathrm{~min}$ while catalyzing syringaldazine (Fig. 3d). In general, bacterial laccases are functional in an alkaline environment and are active at $\mathrm{pH}$ 7.0-8.5, while fungal laccases are partially active in an acidic environment (Claus, 2003; Brander et al., 2014). LacAn is an extracellular thermo-alkali-stable laccase. The alkaline activity of LacAn is similar to those of other bacterial laccases in previous studies (Table S1).
Thus, it may be further applied in industrial and biotechnological field. Additional, $K_{\mathrm{m}}$ and $V_{\max }$ of LacAn for the substrate SGZ were $14.2 \mu \mathrm{M}$ and $10.6 \mu \mathrm{mol}$ $\mathrm{min}^{-1} \mathrm{mg}^{-1}$, respectively.

Metal ions bind to laccases and alter their stability. $\mathrm{Cu}^{2+}$ was important for LacAn activity because no activity was detected for the purified as isolated protein (Fig. 4a). The stimulation of laccase activity by $\mathrm{Cu}^{2+}$ observed in the study occurred probably due to the filling of type I or II copper binding sites with copper ions, highlighting the importance of $\mathrm{Cu}^{2+}$ ion in laccase function (Nagai et al., 2002; Kaushik and Thakur, 2013; Sonica et al., 2014). $\mathrm{Zn}^{2+}$ and $\mathrm{Fe}^{2+}$ decreased LacAn activity to $90 \%$ compared with that without metal ions. Inhibition of LacAn in the presence of $\mathrm{Zn}^{2+}$ was in accordance with the results from previously characterized fungal laccases (Murugesan et al., 2006; Sunil et al., 2018). The inhibition effect of $\mathrm{Fe}^{2+}$ may be due to its interaction with the electron transport system of laccase. The blockage of the access of the substrate or the transfer of electron at the T1 site results in inhibition in laccase activity (Murugesan et al., 2009). LacAn was almost stable in the presence of other metal ions. For example, $\mathrm{Mg}^{2+}$ increased the activity of LacAn to $133 \%$, and $\mathrm{Co}^{2}{ }^{+}$and $\mathrm{Ca}^{2+}$ increased the enzyme activity to $122 \%$ and $106 \%$, 


\section{kDa M control sonicate LacAn}

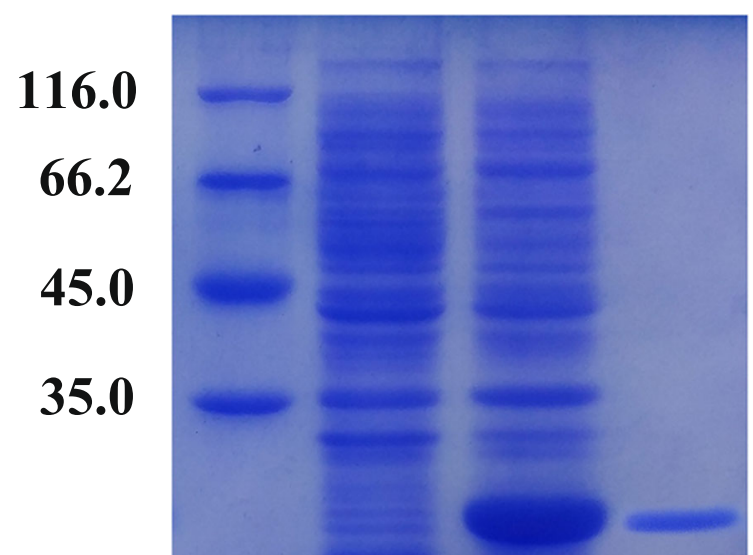

25.0

18.4

14.4

Fig. 2 SDS-PAGE of overexpressed and $\mathrm{Ni}^{2+}{ }_{-} \mathrm{NTA}$ purified LaCAn. Lane M, standard molecular weight marker; lane control, BL21(DE3) without pET22b-lacAn; lane sonicate, sonication product precipitate of BL21(DE3)-pET22b-lacAn; lane LacAn, purified LacAn

respectively, similar to the results reported for $B$. tequilensis, may be due to their interaction with electron transport system of laccase (Sonica et al., 2014, Murugesan et al., 2006). The stability of LacAn in the presence of some metal ions makes LacAn suitable for applications where metal ions are present in high concentrations, such as in the pulp and paper industry and in wastewater containing heavy metals (Shraddha et al., 2011).

In addition, potential inhibitors exerted various effects on LacAn activity. Ionic surfactants reportedly inhibit laccase activity (Robles et al., 2002; Zhang et al., 2013). Under the above reaction conditions, $0.5 \mathrm{mM}$ SDS significantly inhibited the enzyme activity, and only $13 \%$ of the enzyme activity was retained. This result may be due to binding of the ionic surfactant [below Critical Micelle Concentration (CMC)] to the enzyme which may cause the alterations in its enzymatic and physical characteristics (Robles et al., 2002; Sonica et al., 2014; Zhang et al., 2013). The effect of $10 \mathrm{mM}$ EDTA was slightly weaker than SDS with $22 \%$ of the activity was retained, due to the deprivation of the $\mathrm{Cu}^{2+}$ ions present at type 1 copper center and inhibit the enzyme activity
(Kaushik and Thakur, 2013). When DMSO and ethanol organic solvents were added, about $50 \%$ of the enzyme activity was retained (Fig. 5). However, as a comparison, ionic surfactants reportedly stimulate the activity of laccase from Azospirillum lipoferum and B. tequilensis (Diamantidis et al., 2000; Sonica et al., 2014).

\section{Decolorization of azo dyes by LacAn}

The ability of LacAn to oxidize dyes was tested by single-factor optimization. When the five dyes were oxidized, the decolorization rates remained high when the $\mathrm{pH}$ was at 8.5 (Fig. 5a). The highest decolorization rates were achieved at $\mathrm{pH} 7.5$, which was then chosen as the optimum $\mathrm{pH}$ and suitable for industrial applications. The temperatures were set at the range of $55-80{ }^{\circ} \mathrm{C}$. Results showed that LacAn had good catalytic properties at high temperature and remained active within a wide temperature range. A high decolorization rate was achieved even at $80{ }^{\circ} \mathrm{C}$ (Fig. 5b). In addition, all five dyes were efficiently decolorized and the highest decolorization rates were observed even when $200 \mathrm{U} / \mathrm{L}$ LacAn was added (Fig. 5c). The decolorization rates of the dyes increased when the reaction time was extended. Finally, the highest decolorization rates of the five dyes showed that direct blue 6 and acid black 1 reached $33.15 \% \pm 2.69 \%$ and $31.08 \% \pm 1.31 \%$, respectively, at $100 \mathrm{~min}$ of reaction. At $60 \mathrm{~min}$ of reaction, direct green 6 and direct black 19 reached 99.64\% \pm $1.13 \%$ and $51.34 \% \pm 1.66 \%$, respectively. Acid blue 93 reached $34.45 \% \pm 1.52 \%$ at $80 \mathrm{~min}$ (Fig. $5 \mathrm{~d}$, Table 2).

Laccase can oxidize a variety of substrates for industrial applications, especially for the oxidation of dyes in industrial wastewater treatment, which has important environmental significance (Verma and Madamwar, 2003; Rai et al., 2005). LacAn is a bacterial laccase with high catalytic activity in alkaline $\mathrm{pH}$. In this study, LacAn was able to oxidize five dyes under neutral to alkaline conditions and still had higher decolorization rates even at $\mathrm{pH} 8.5$ (Fig. 5a). This result indicates that the bacterial laccase has better decolorization characteristics than fungal laccases under neutral alkaline conditions.

Most of the reported decolorization reaction temperatures of bacterial laccase are between 30 and $45{ }^{\circ} \mathrm{C}$. With the increase in temperature, the activity of laccase decreased and the decolorization ability decreased, which limited the application of laccase decolorization (Kalmea et al., 2009; Molina-Guijarro et al., 2009; Pereira et al., 2009; Liu et al., 2011; Lu et al., 2012). LacAn can still decolorize dyes effectively at $80{ }^{\circ} \mathrm{C}$, especially direct green 6 with a high decolorization rate of $99 \%$ (Fig. 5b). It enables LacAn to oxidize dyes at low and high temperatures and also shortens the reaction time at high temperatures, revealing its advantage of high temperature decolorization. LacAn has the 

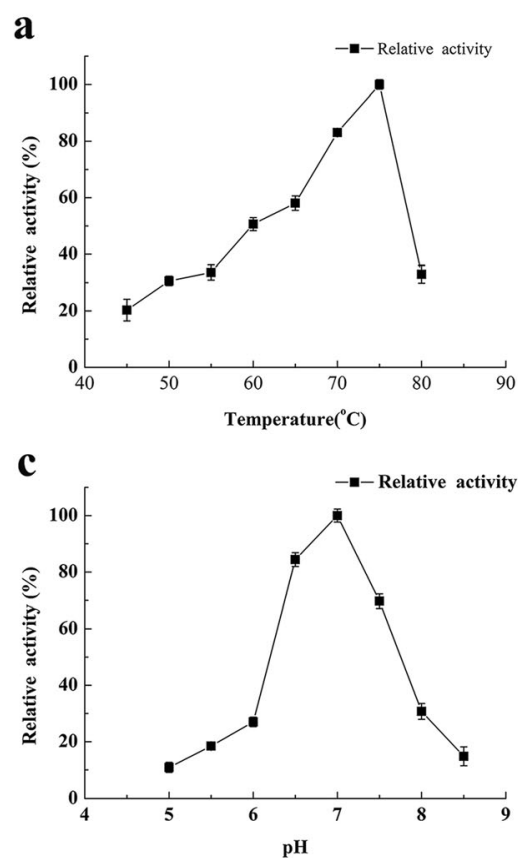
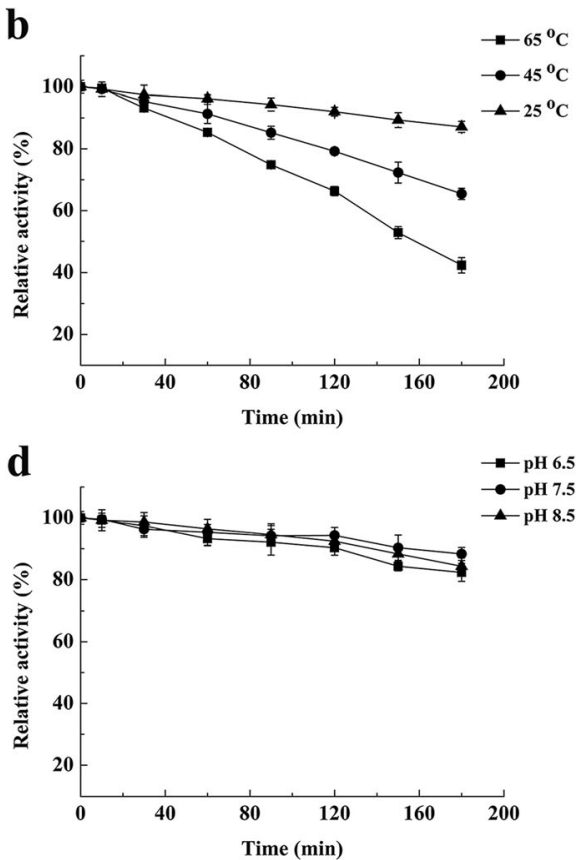

Fig. 3 Effects of $\mathrm{pH}$ and temperature on the activity and stability of LacAn. a Optimum temperature of LacAn for enzyme activity was measured in $50 \mathrm{mM} \mathrm{Na}_{2} \mathrm{HPO}_{4}-\mathrm{KH}_{2} \mathrm{PO}_{4}$ at $\mathrm{pH} 7.0$ with syringaldazine as a substrate. b Thermostability was investigated at $25^{\circ} \mathrm{C}$ (triangle), $45^{\circ} \mathrm{C}$ (circle), and $65^{\circ} \mathrm{C}$ (square) by determining the enzyme activity under the same conditions as above. c Optimum pH of LacAn for enzyme activity was measured in $50 \mathrm{mM} \mathrm{Na} 2 \mathrm{HPO}_{4}-\mathrm{KH}_{2} \mathrm{PO}_{4}$ at $75{ }^{\circ} \mathrm{C}$ with syringaldazine as a substrate. $\mathbf{d}$ pH stability was investigated at pH 8.5 (triangle), pH 7.5 (circle), and pH 6.5 (square) by determining the enzyme activity under the same conditions as above. Error bars represent standard deviations

advantage of high temperature application even in laccase derived from thermophilic bacteria. Compared with a laccase named TthLAC from Thermus thermophilus, when the azo dyes were oxidized by the TthLAC, the efficient decolorization was at temperature of $60-65{ }^{\circ} \mathrm{C}$. It made the LacAn more widely used (Kumari et al., 2018).

The spatial structure of the dye macromolecule hinders its binding with the active center of the enzyme. Most laccases have low redox potential. Mediators such as ABTS and syringaldehyde must be added to oxidize dye substrates to complete the catalytic reaction and increase the decolorization efficiency (Guan et al., 2012; Yang et al., 2018). For example, the laccase LaclK from Kurthia huakuii was used to oxidize azo dyes (Guo et al., 2016). Only when ABTS was added as a mediator, LaclK showed obvious decolorization ability (Guo et al., 2016). A laccase derived from Bacillus subtilis cjp3 was used for dye oxidative decolorization, and results showed
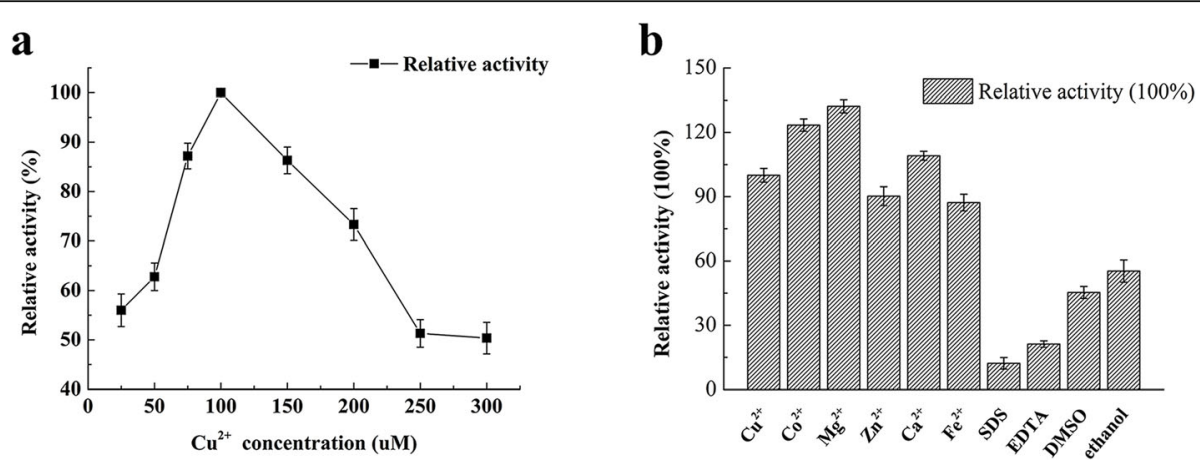

Fig. 4 Effects of $\mathrm{Cu}^{2+}$, metal ions, inhibitors, and organic solvent on the enzyme activity of LacAn. a Optimum $\mathrm{Cu}^{2+}$ concentration of LacAn for enzyme activity was measured in $50 \mathrm{mM} \mathrm{Na} 2 \mathrm{HPO}_{4}-\mathrm{KH}_{2} \mathrm{PO}_{4}$ at $75{ }^{\circ} \mathrm{C}$ and $\mathrm{pH} 7.0$ with syringaldazine as a substrate. $\mathbf{b}$ Effects of metal ions, inhibitors, and organic solvent on the enzyme activity of LacAn. The enzyme activity was measured in $50 \mathrm{mM} \mathrm{Na}_{2} \mathrm{HPO}_{4}-\mathrm{KH}_{2} \mathrm{PO}_{4}$ at $75{ }^{\circ} \mathrm{C}$ and $\mathrm{pH}$ 7.0 with syringaldazine as a substrate, supplemented with $0.1 \mathrm{mM} \mathrm{CuSO}_{4}$. Error bars represent standard deviations 

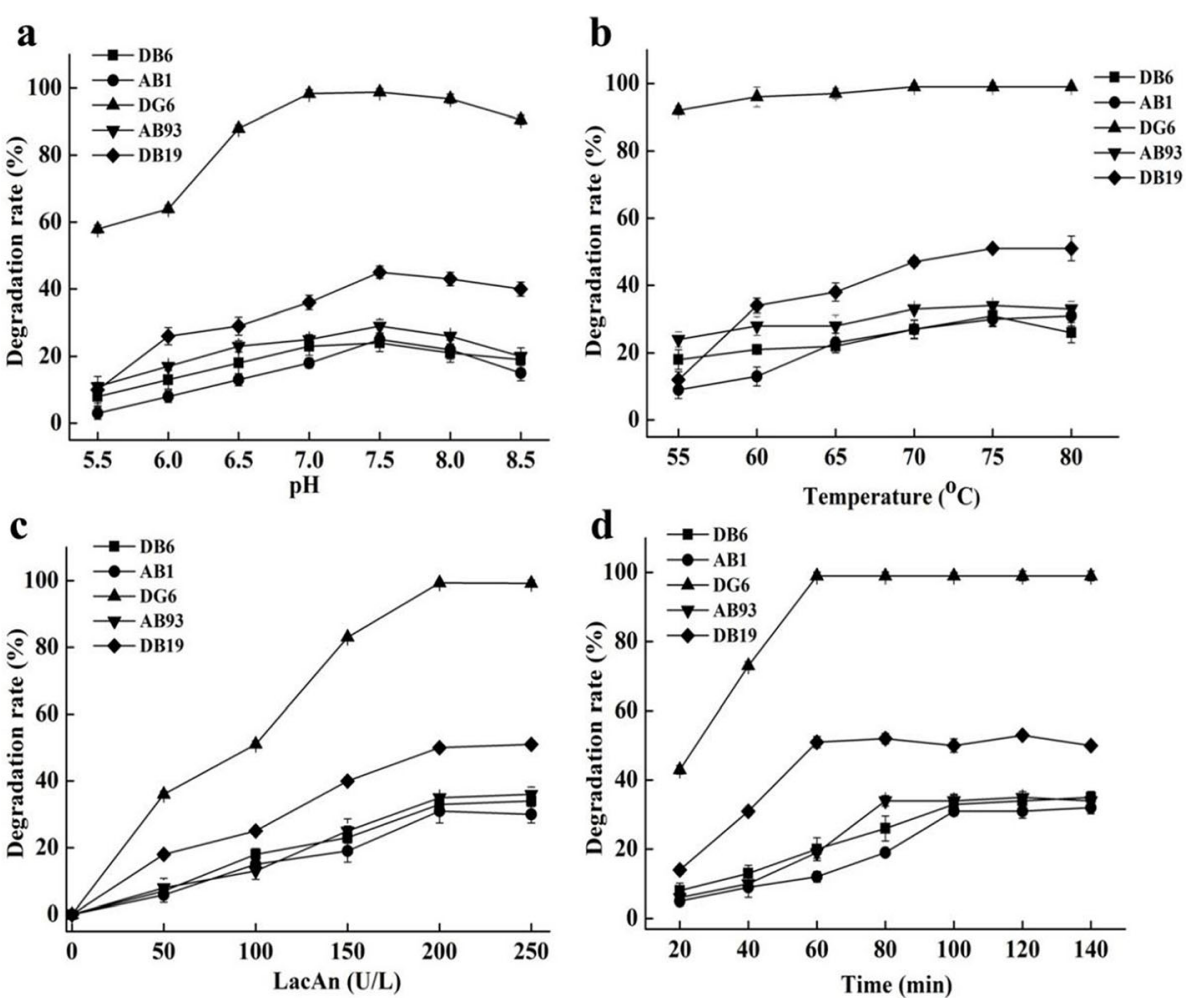

Fig. 5 Effect of pH (a), temperature (b), concentration of LacAn (c), and time (d) on the decolorization rate of LacAn oxidation dyes. The values and standard deviations were calculated based on three independent experiments

that reactive blue 19 , reactive black 5 , and indigo carmine can be effectively decolored by purified laccase with ABTS as a mediator. More than $86 \%$ of the dyes tested were removed at $4 \mathrm{~h}$ (Qiao et al., 2017). For the above laccases, without a mediator, there was no decolorization ability. But LacAn had an effective decolorization ability when the mediator was absent. Although the mediator could improve the decolorization efficiency, it would cause more pollution and increase the cost of decolorization. Due to the lack of mediators in decolorization, LacAn will have more important application value.

The LacAn used in this study still had a good decolorization effect on the selected dyes within a short reaction time even without any mediators (Fig. 5, Table 2).

Table 2 The conditions of dyes oxidized with LacAn

\begin{tabular}{llllll}
\hline Dyes & $\mathrm{pH}$ & Temperature, $^{\circ} \mathrm{C}$ & Laccase, $\mathrm{U} / \mathrm{L}$ & Time, min & $\begin{array}{l}\text { Decolorization } \\
\text { rate, } \%\end{array}$ \\
\hline DG6 & 7.5 & 70 & 200 & 60 & $99.64 \pm 1.13$ \\
DB19 & 7.5 & 70 & 200 & 60 & $51.34 \pm 1.66$ \\
DB6 & 7.5 & 70 & 200 & 100 & $33.15 \pm 2.69$ \\
AB1 & 7.5 & 70 & 200 & 100 & $31.08 \pm 1.31$ \\
AB93 & 7.5 & 70 & 200 & 80 & $34.45 \pm 1.52$ \\
\hline
\end{tabular}

This result may be due to the better catalytic activity and stability of LacAn. Thus, LacAn has a wide application prospect in industrial wastewater treatment.

\section{Conclusion}

A bacterial laccase (LacAn) from Anoxybacillus ayderensis SK3-4 was cloned and successfully expressed in E. coli. The purified enzyme is smaller than other known laccases. In terms of biochemical characteristics, the optimum $\mathrm{pH}$ and temperature for SGZ oxidation were 7.0 and $75{ }^{\circ} \mathrm{C}$, respectively. LacAn was stable at $\mathrm{pH}$ values ranging from 6.5 to 8.5 above $65^{\circ} \mathrm{C}$. Moreover, LacAn showed desirable stability at high temperatures and alkaline $\mathrm{pH}$, and dye decolorization ability. These properties render LacAn a prospect for further industrial applications.

\section{Supplementary information}

Supplementary information accompanies this paper at https://doi.org/10. 1186/s13213-020-01593-6.

Additional file 1. Figure S1. DNA sequence of LacAn after codon optimizaion

Additional file 2. Figure S2. The chemical structures of the 5 synthetic dyes 
Additional file 3. Table S1. Characteristics of LacAn compared with reported prokaryotic laccases

\section{Research involving human participants and/or animals}

N/A

\section{Informed consent}

N/A

\section{Authors' contributions}

The author(s) read and approved the final manuscript.

\section{Funding}

This work was funded by the Natural Science Foundation of Anhui Province (1708085QC68), National Natural Science Foundation of China (31800049), National Natural Science Foundation of China (31800042), Foreign Visiting Program for Young Outstanding Talents in Anhui Province (gxgwfx2018067), and Talent Research Fund Project of Hefei University (16-17RC05)

\section{Competing interests}

The authors declare that they have no conflict of interest

\section{Author details}

${ }^{1}$ School of Life Science, Hefei Normal University, Hefei 230601, Anhui, China. ${ }^{2}$ School of Biology, Food and Environment, Hefei University, Hefei 230601 Anhui, China. ${ }^{3}$ Department of Chemistry \& Biochemistry, Florida International of University, Miami, FL 33199, USA. ${ }^{4}$ Agricultural Engineering Research Institute, Anhui Academy of Agricultural Sciences, Hefei 230031, Anhui, China.

Received: 5 February 2020 Accepted: 28 July 2020

Published online: 14 August 2020

\section{References}

Ausec L, Zakrzewski M, Goesmann A, Schluter A, Mandic-Mulec I (2011) Bioinformatic analysis reveals high diversity of bacterial genes for laccase-like enzymes. PLoS ONE 6:e25724

Baldrian P (2006) Fungal laccases - occurrence and properties. FEMS Microbiol. Rev 30:215-242

Beloqui A, Pita M, Polaina J, Martinez-Arias A, Golyshina OV, Zumarraga M, Yakimov MM, Garcia-Arellano H, Alcalde M, Fernandez VM, Elborough K, Andreu JM, Ballesteros A, Plou FJ, Timmis KN, Ferrer M, Golyshin PN (2006) Novel polyphenol oxidase mined from a metagenome expression library of bovine rumen: biochemical properties, structural analysis, and phylogenetic relationships. J Biol Chem 281:22933-22942

Brander S, Mikkelsen J D, Kepp K P (2014) Characterization of an alkali and halideresistant laccase expressed in E. coll: CotA from Bacillus clausii. PLoS One 9: e99402

Brijwani K, Rigdon A, Vadlani PV (2010) Fungal laccase: production, function, and applications in food processing. Enzyme Res 2010:149748

Claus H (2003) Laccases and their occurrence in prokaryotes. Arch Microbiol 179: $145-150$

Diamantidis G, Effosse A, Potier P, Bally R (2000) Purification and characterization of the first bacterial laccase in the rhizospheric bacterium Azospirillum lipoferum. Soil Biol Biochem 32:919-927

Fang ZM, Li TL, Wang Q, Zhang XC, Peng H, Fang W, Hong YZ, Ge HH, Xiao YZ (2011) A bacterial laccase from marine microbial metagenome exhibiting chloride tolerance and dye decolorization ability. Appl Microbiol Biotechno 89:1103-1110

Feng HW, Zhang D, Sun YJ, Zhi Y, Mao L, Luo YQ, Xu L, Wang LM, Zhou P (2015) Expression and characterization of a recombinant laccase with alkalistable and thermostable properties from Streptomyces griseorubens. Appl Biochem Biotechnol 176:547-562

Guan ZB, Zhang N, Song CM, Zhou LX, Zhao H, Xu CW, Cai YJ, Liao XR (2012) Molecular cloning, characterization, and dye-decolorizing ability of a temperature- and pH-stable laccase from Bacillus subtilis X1. Appl Biochem Biotechnol. 172:1147-1157

Gunne M, Urlacher VB (2012) Characterization of the alkaline laccase Ssl1 from Streptomyces sviceus with unusual properties discovered by genome mining PLoS One 7:e52360
Guo X, Zhou S, Wang YW, Song JL, Wang HM, Kong DL, Zhu J, Dong WW, He MX, Hu GQ, Ruan ZY (2016) Characterization of a highly thermostable and organic solvent-tolerant copper-containing polyphenol oxidase with dyedecolorizing ability from Kurthia huakuii LAM0618T. PLoS One 14:e0164810

Hilden K, Hakala TK, Lundell T (2009) Thermotolerant and thermostable laccases. Biotechnol Lett 31:1117-1128

Hoegger PJ, Kilaru S, James TY, Thacker JR, Kües U (2006) Phylogenetic comparison and classification of laccase and related multicopper oxidase protein sequences. FEBS I 273:2308-2326

Kahar UM, Chan KG, Salleh MM, Hii SM, Goh KM (2013) A high molecular-mass Anoxybacillus sp. SK3-4 amylopullulanase: characterization its relationship in carbohydrate utilization. Int J Mol Sci 28 14(6):11302-11318

Kalmea S, Jadhavb S, Jadhavb M, Govindwar S (2009) Textile dye degrading laccase from Pseudomonas desmolyticum NCIM 2112. Enzyme Microb Technol 44:65-71

Kaushik G, Thakur IS (2013) Purification, characterization and usage of thermotolerant laccase from Bacillus sp. for biodegradation of synthetic dyes. Appl Biochem Microbiol 49:352-359

Kudanga T, Le Roes-Hill M (2014) Laccase applications in biofuels production: current status and future prospects. Appl Microbiol Biotechnol 98:6525-6542

Kumari A, Kishor N, Guptasarma P (2018) Characterization of a mildly alkalophilic and thermostable recombinant Thermus thermophilus laccase with applications in decolorization of dyes. Biotechnol Lett 40:285-295

Leonowicz A, Cho NS, Luterek J, Wilkolazka A, Wasilewska MW, Matuszewska A, Hofrichter M, Wesenberg D, Rogalskai I (2001) Fungal laccase: properties and activity on lignin. Basic Microbiol 41:185-227

Liu YH, Ye M, Lu Y, Zhang X, Li G (2011) Improving the decolorization for textile dyes of a metagenome derived alkaline laccase by directed evolution. Appl Microbiol Biotechnol 91:667-675

Lu L, Zhao M, Wang TN, Zhao LY, Du MH, Li TL, Li DB (2012) Characterization and dye decolorization ability of an alkaline resistant and organic solvents tolerant laccase from Bacillus licheniformis LS04. Bioresour Technol 115:35-40

Mate DM, Alcalde M (2016) (2016) Laccase: a multi-purpose biocatalyst at the forefront of biotechnology. Microb Biotechnol. 10:1457-1467

Miyazaki K (2005) A hyper thermophilic laccase from Thermus thermophilus HB27. Extremophiles 9:415-425

Molina-Guijarro JM, Perez J, Munoz-Dorado J, Guillen F, Moya R, Hernandez M, Arias ME (2009) Detoxification of azo dyes by a novel pH-versatile, saltresistant laccase from Streptomyces ipomoea. Int Microbial 12:13-21

Murugesan K, Arulmani M, Nam IH, Kim YM, Chang YS, Kalaichelvan PT (2006) Purification and characterization of laccase produced by a white rot fungus Pleurotus sajorcaju under submerged culture condition and its potential in decolorization of azo dyes. Appl Microbiol Biotechnol 72:939-946

Murugesan K, Kim Y, Jeon J, Chang Y (2009) Effect of metal ions on reactive dye decolorization by laccase from Ganoderma lucidum. J Hazard Mater 168:523-529

Nagai M, Sato T, Watanabe H, Saito K, Kawata M, Enei H (2002) Purification and characterization of an extracellular laccase from the edible mushroom Lentinula edodes, and decolorization of chemically different dyes. Appl Microbiol Biotechnol 60:327-335

Othman AM, Elsayed MA, Elshafei AM, Hassan MM (2018) Purification and biochemical characterization of two isolated laccase isoforms from Agaricus bisporus CU13 and their potency in dye decolorization. International Journal of Biological Macromolecules 113:1142-1148

Pereira L, Coelho AV, Viegas CA, Santos MM, Robalo MP, Martins LO (2009) Enzymatic biotransformation of the azo dye Sudan Orange $\mathrm{G}$ with bacterial CotA-laccase. J Biotechnol 139:68-77

Qiao W, Chu J, Ding S, Song X, Yu L (2017) Characterization of a thermo-alkali-stable laccase from Bacillus subtilis cjp3 and its application in dyes decolorization. J Environ Sci Health A Tox Hazard Subst Environ Eng 52:710-717

Rai HS, Bhattacharya MS, Singh J, Bansal TK, Vats P, Banerjee UC (2005) Remova of dyes from the effluent of textile and dyestuff manufacturing industry: a review of emerging techniques with reference to biological treatment. Crit Rev Environ Sci Technol 35:219-238

Robles A, Lucas R, Martinez-canamero M, Omar NB, Peres R, Galvez A (2002) Characterization of laccase activity produced by the hyphomycete Chalara (syn. Thielaviopsis) paradoxa CH32. Enzyme Microb Technol 31:516-522

Sharma P, Goel R, Capalash N (2007) Bacterial laccases. World J Microbiol Biotechnol 23:823-832

Shraddha SR, Sehgal S, Kamthania M, Kumar A (2011) Laccase: microbial sources, production, purification, and potential biotechnological applications. Enzyme Res. https://doi.org/10.4061/2011/217861 
Sonica S, Prince S, Shilpa S, Neena P, Naveen G (2014) Purification and characterization of an extracellular, thermo-alkali-stable, metal tolerant laccase from Bacillus tequilensis SN4. PLOS ONE 9:e96951

Sunil G, Youri Y, Woo-Young S, Tae-Young K, Hor-Gil H (2018) A novel laccase from thermoalkaliphilic bacterium Caldalkalibacillus thermarum strain TA2.A1 able to catalyze dimerization of a lignin model compound. Appl Microbiol Biotechnol 102:4075-4086

Telke AA, Ghodake GS, Kalyani DC, Dhanve RS, Govindwar SP (2011) Biochemical characteristics of a textile dye degrading extracellular laccase from a Bacillus sp. ADR. Bioresour Technol 102:1752-1756

Verma P, Madamwar D (2003) Decolourization of synthetic dyes by a newly isolated strain of Serratia marcescens. World J Microbiol Biotechnol 19: 615-618

Yang Q, Zhang M, Zhang M, Wang C, Liu Y, Fan X, Li H (2018) Characterization of a novel, cold-adapted, and thermostable laccase like enzyme with high tolerance for organic solvents and salt and potent dye decolorization ability, derived from a marine metagenomic library. Front Microbiol. https://doi.org/ 10.3389/fmicb.2018.02998

Zhang C, Zhang S, Diao H, Zhao H, Zhu X, Lu F, Lu Z (2013) Purification and characterization of a temperature and $\mathrm{pH}$-stable laccase from the spores of Bacillus Vallismortis fmb-103 and its application in the degradation of malachite green. J Agric Food Chem 61:5468-5473

\section{Publisher's Note}

Springer Nature remains neutral with regard to jurisdictional claims in published maps and institutional affiliations.

Ready to submit your research? Choose BMC and benefit from:

- fast, convenient online submission

- thorough peer review by experienced researchers in your field

- rapid publication on acceptance

- support for research data, including large and complex data types

- gold Open Access which fosters wider collaboration and increased citations

- maximum visibility for your research: over $100 \mathrm{M}$ website views per year

At BMC, research is always in progress.

Learn more biomedcentral.com/submissions 